\title{
Application of Lean Methods into the Customised Product Development Process of Large Power Transformers
}

\author{
Mitja VARL, Jožef DUHOVNIK, Jože TAVČAR
}

\begin{abstract}
The study conducts research on lean product development (PD) methodology and presents a case study of its practical application into a specific one-of-a-kind development of large power transformers. The demonstrated framework is the result of a 5 -year intensive research that led to an extensive transformation of a traditional PD environment into a highly efficient process according to lean principles. Paper explains how lean PD integrates with robust, concurrent and smart design strategies in highly individualized PD business. A generalized framework of PD and design process renovation is presented, comprising three main fields of interest: Process \& Tools, People, and Knowledge. A direct consequence of implied renovation are significant savings. Case-study company cut down engineering changes by $32 \%$ in three year test period and experienced performance improvement between $25 \%$ and $83 \%$ across designated process indicators.
\end{abstract}

Keywords: lean product development; one-of-a-kind production; set-based concurrent engineering; smart industry; Toyota product development system

\section{INTRODUCTION}

Lean thinking studies organization's value streams, removing all non-value adding activities, and constantly aligning all respective activities to the external and internal customers. The results, and particular characteristics of any lean system, are short lead-times, reduced requirements for human and financial resources, as well as products that are particularly suited to fulfil customer requirements [1-3]. Lean thinking has been studied for approximately two decades with main focus on manufacturing processes optimization [4, 5]. However, new engineering products continue to under-perform with regard to their lead times, cost, and quality. There has been relatively less research done to apply 'lean' to product and process development (PPD). This is quite unusual, as PPD has the greatest influence on the economic success of any product as recognised by Khan [6]. A lack of application of the lean principles to PD was emphasized also by numerous other authors [7-9]. Furuhjelm et al. note that while Toyota's production system - or Lean Production, as it is generally denoted in the West - has been thoroughly researched, the principles and methods applied in Toyota's PD are less understood [10]. Additionally, Baines et al. argue that this is reflected in the literature on lean product development (LPD), which is not as widespread as the lean production and manufacturing literature [11]. Hoppmann et al. even argue that there is no agreement about precise LPD definition [12]. Lean and agile production is the capability of a manufacturer to operate profitably in an environment of continually and unpredictably changing customer demands [13]. Nevertheless, it is obvious that the mechanisms of value creation in the production and PD environment are considerably different. Lean production is generally focused on reduction of waste, as shorter manufacturing lead-time means direct savings. However, savings during the PD process are considerably more complex and therefore difficult to recognize. They have to be evaluated with respect to the entire product lifecycle. Deliberate repetition of certain operations generates a new knowledge, which in fact adds a value to the process. As demonstrated later in the article, straightforward conversion of lean manufacturing principles into PD environment is usually inappropriate and even harmful, mainly because of unjustified creativity restraints.
However, creativity is proved to be a fundamental component of any PD.

Based on an extensive and systematic research of relevant literature and considerable experience, gained in the real industrial environment producing technically advanced and highly individualized products, this study demonstrates the transformation of a traditional PD environment into a highly efficient process according to lean principles, deriving from the Toyota product development system (TPDS). Based on a real case study, this paper presents an original framework of the LPD process under the demanding conditions of a specific oneof-a-kind industrial environment. The systematic approach for the comprehensive renovation of PD has resulted in an increased product efficiency and robustness for the overall process. This study sheds light on how to approach such transformation challenges and the presented case study offers valuable insights into how to implement appropriate measurements in a real, highly individualized, PD environment. This field, while well researched, lacks comprehensive coverage of the entire lean implementation process. A generalized form of the proposed framework is the main contribution of this study, as it presents a universal solution for such a specific business environment, thus, filling the mentioned gap in the literature.

\section{LITERATURE REVIEW}

\subsection{Lean Methodology}

Womack et al. and Clark et al. emphasized four key attributes of lean design: leadership, teamwork, communication, and simultaneous development [14, 15]. Later, Karlsson and Ahlström elaborated on their own version of LPD [16]. Following their definition, LPD includes six strategies: involvement of suppliers, concurrent engineering, cross-functional teams, integration of activities, a heavyweight team structure, and strategic management of projects.

The theory of Set-Based Concurrent Engineering (SBCE) was a considerable momentum for the review and expansion of existing LPD concepts. Morgan and Liker emphasized the management aspects of the TPDS and underscored the importance of system integration [17]. These management aspects were categorized into three 
LPD subsystems: people, process and tools, and techniques. According to Ward an LPD system comprises five major principles: value focus, entrepreneur system designer, set-based simultaneous engineering, cadence, flow and pull, and a team of responsible experts [18]. Stjepandić et al. contributed to concurrent engineering (CE) with their comprehensive book comprising extensive theoretical background with contemporary case studies [19]. LPD can improve the performance of complex projects by identification of major wastes according to Belvedere et al. [20].

In the following subsections, all the above-mentioned findings and ideas are explained in detail. Currently, there seems to be a lack of structured industrial and academic research on the application of lean concepts into PD process under the specific conditions of a highly individualized business environment. Most of the existing literature focuses on the application of lean principles into the serial production domain. Therefore, this study aims to bridge this gap by studying if and how experiences and results of successful PD process transformation, in the serial production environment, can be introduced into a one-of-a kind business model. Currently, the principles of smart factory are one of the cutting-edge fields of research in contemporary professional literature. We have noticed strong analogy between the application of lean methods and smart principles as recognized for example in Industry $4.0[21-23]$.

\subsection{Lean Product Development}

LPD discusses how the general idea of lean thinking can be applied to the field of PD to achieve a valueoriented, resource-efficient, and fast product innovation process [12]. LPD is a knowledge based process, therefore, the emphasis is on learning and capturing knowledge to be applied to current and future products. This requires maximizing the exploration time, during which multiple alternative implementations are examined. Learning minimizes the failures and rework loops are encountered when design is based on insufficient knowledge.

Letens et al. argue that differentiation between the value-added activities that characterize lean production on one side and lean development on the other is of a great importance [24]. LPD must differ substantially from lean manufacturing because PD has different economics and value creation mechanisms [25]. For example, activities connected with tests and experiments may lead to valuable new outcomes and data. A systematic detection of waste in PD is mainly based on the analysis of the value stream mapping (VSM). In this respect VSM was recognised as a successful tool [26, 27]. Having identified a waste occurrence, the next action towards avoiding unnecessary activities is to investigate and remove its causes [9]. To find such causes, a numerous tools and techniques have been developed to achieve a sustainable deletion of waste, for example quality function deployment (QFD), design structure matrix (DSM), set-based engineering (SBE), conjoint analysis, or Toyota's 'five whys technique'. Veza et al. made a selection of six basic lean tools, and foundations of generic configuration of innovative smart enterprise model are defined [28]. In their extensive research, Kennedy et al. executed an in-depth analysis of the rework phenomenon [29]. They discovered that a number of PD practices, which have been characterized as a shift from developing a single-point design to developing a set of possible designs, have proven effective at reducing development rework. Since the generated set-based knowledge is often reusable on future projects, the positive benefits often multiply several times over.

Based on extensive and systematic literature review we can predict an approximate framework for the realization of our later case study, Fig. 1.

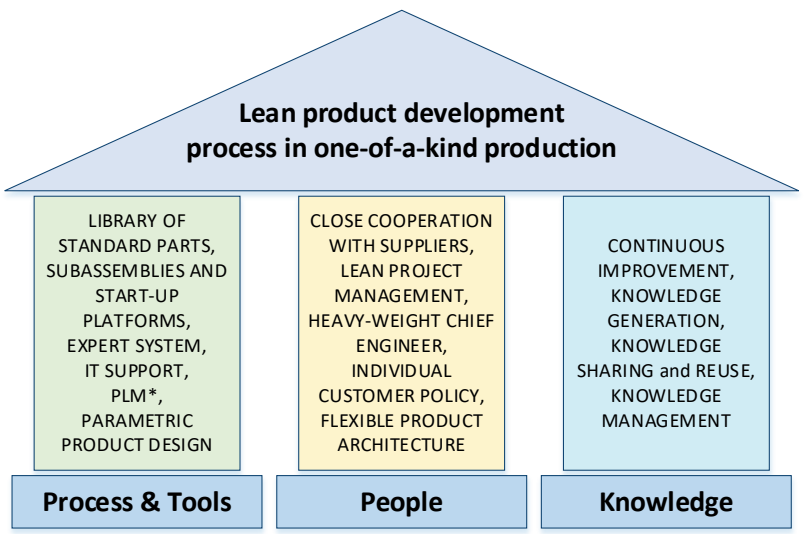

Figure 1 House of LPD process in one-of-a-kind business environment, based on conducted literature review ("PLM - Product Lifecycle Management).

\section{A REAL INDUSTRIAL BACKGROUND}

The sample company is a renowned manufacturer of power transformers. For the purposes of this article "large power transformers" should be understood as power transformers of rated power from 10 MVA to 400 MVA and rated voltage up to $400 \mathrm{kV}$. The nature of its business makes this company ideal for a case study selection, as it is a typical representative of a one-of-a kind business environment. The design of each new power transformer suits to an adaptive type of design. For example, when a new design problem arises, it is resolved via the alteration of an existing design instead of carrying out the design process from the beginning. Because of the complexness, associated cost, and overall uncertainty of performing the creative design process, significant value exists in reusing existent design data and knowledge [30]. To discover more about design levels and adaptive design aspects, see [31, 32].

The basic working principles together with the auxiliary functional requirements are fully known and the approximate design model is adequately structured with well-defined interfaces among different modules. By each project development and design activities start from the same baseline, which is the selection of the appropriate parametric 3D model layout. The general design and functional characteristics of different subassemblies or modules are generally known in advance. Parametric models consist of smart subassemblies and parts, the design of which is well-considered and based on experience and knowledge of the company, together with a number of standard components. Thus, the key issue of any new design is expressed in the search for a new technical shape that would optimally meet the individual requirements of each individual customer, Fig. 2 and 3. Although development and design department established well-structured and content-rich parametric layouts, 
assemblies and parts, each new individual contract requires specific design solutions and modification of the numerous details, which makes each final product unique. The individualization process includes the parametric change of in advance prepared components and sometimes a certain degree of completely new-designed components.

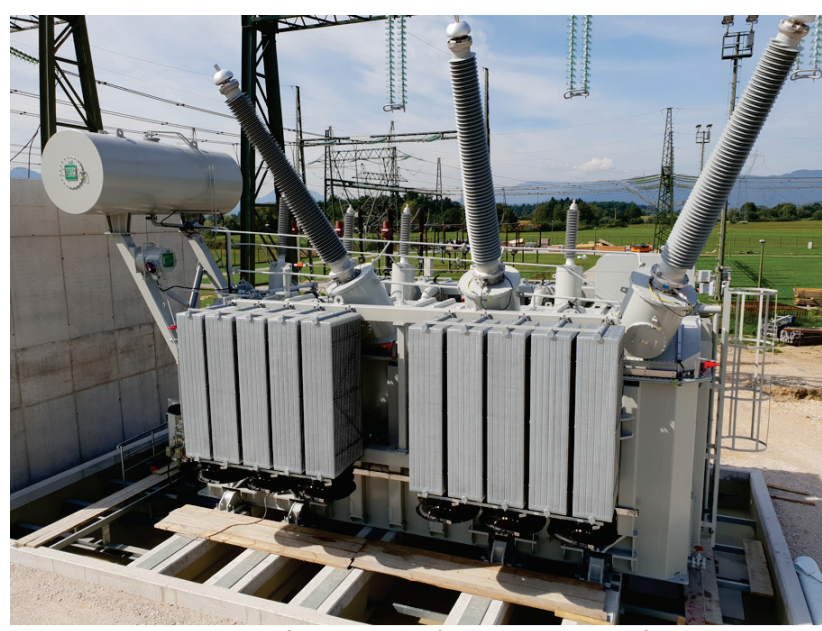

Figure 2 An example of a power transformer $A$, where the functionality is realized with a specific shape model.

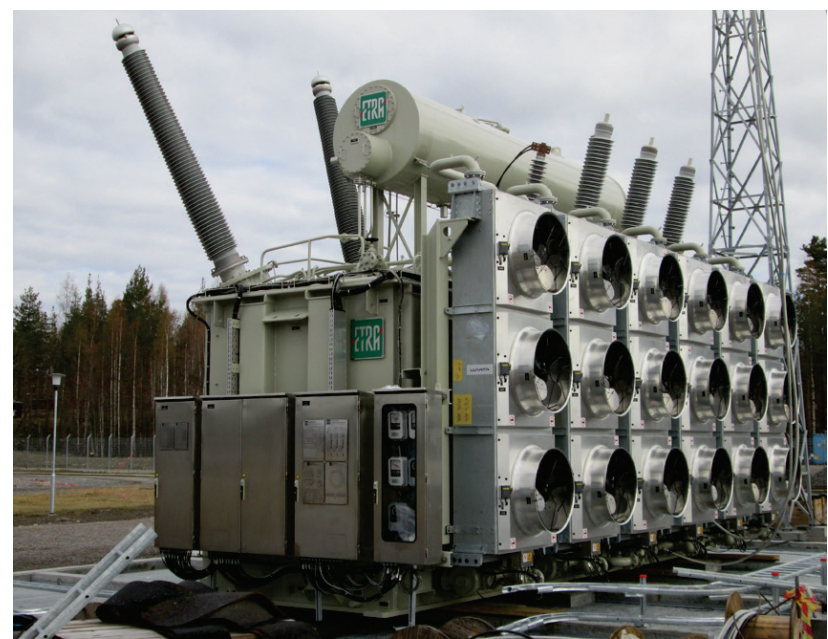

Figure 3 An example of a power transformer $B$, where the same functionality is realized with a significantly different shape model as in Fig. 2.

The PD process in the case-study company is recognized as the most challenging, regarding technical and time-to-market aspects. Considerable part of the company's financial losses is generated through the errors during the PD. The development and design process strongly influences all further production activities. A high ratio of product individualization has a serious influence on the potentially reduced leanness of the design process. The human factor is also important as it directly affects the overall quality of an end product through the number of errors and engineering changes. The core of this research was therefore based on the search for development and design process alternatives of individualized products, where the target function is the elimination of the human factor within the limits of everyday engineering usability and economic viability. We argue that on a basis of systematic analysis of a development and design process, it is possible to establish a smart system of information and methodological support and reorganize the activities in a way that makes a design process lean and thus effective.

\section{LEAN METHODOLOGY AND ONE-OF-A-KIND PRODUCTION}

This chapter presents in detail a case study and the resultant generalized novel framework of LPD process for one-of-a-kind production (OKP) environment. However, the recognition of differences and exceptions is crucial for its successful introduction into the discussed business environment. As TPDS was systematically developed in serial industrial environment, the most important aspects of its application into the one-of-a-kind PD environment are presented and analysed in this chapter. The demonstrated framework is the result of a 5-year intensive research that led to an extensive transformation of a traditional PD environment into a highly efficient process according to lean principles. We divided LPD principles into three main groups: Process \& tools, People, and Knowledge. As it turned out, the principles under the groups of People and Knowledge may be generalized in a great manner. Furthermore, the principles of the group Process \& tools are complex and strongly define any PD process. They have to be attentively tuned with the nature of the respective PD process. TPDS cannot be simply introduced into one-of-a-kind business environment, rather it has to be individually altered to optimally accommodate the respective process.

\subsection{Process \& Tools Level}

The customer is always the starting point of any process. Adding value at Toyota is defined by the customer's (perceived) value. Waste is what costs time, money, and resources, but does not always add value from the customer's perspective. Value stream mapping (VSM) is an important tool of the lean approach, which strives to place sequential operations in the correct order to ensure a smooth execution of PD activities [33].

In a case study, PD transformation started with the definition of a strategic action plan, based on the value stream analysis. The company got, in this way, an accurate and broad picture of the current business state. To early convergence on the inappropriate solution involves undesired costs throughout the product life cycle. Taking time for in-depth exploration of alternative solutions and resolve expected issues at the root cause results in multiple advantages. In the adaptive type of PD process, a new design problem is usually solved through the modification of an existing design solution rather than performing the design process from sketch. Although there is always a certain degree of components which undergo a completely new design, quick and robust adaptation of pre-existing design solutions remains the major part of the discussed one-of-a-kind PD process (to discover more about robust design in OKP domain, see [34]). This is the reason why the aspect of reasonable standardization is so important. The challenge is to reduce variation while preserving the creativity that is necessary for the creative process. Standardization enables the creation of highly stable and predictable outcomes with both quality and timing in an unpredictable environment. Main activities presented in generalised way in the process domain are presented in Tab. 1. 


\subsection{People Level}

One of the important principles of lean methodology is levelling the flow. It starts with stabilizing the process to be predicted and appropriately planned. This allows product planning to reduce major swings in workload. Predictable workload swings can be staffed through flexible labour pools. Once the value has been defined and the majority of engineering and design challenges resolved (i.e. achieved basic design stability), LPD requires a wastefree process to speed the product to the market.
Another important aspect is the development of a functional design team hierarchy via proper project team formation. The chief engineer has a role of master designer and product leader with the final authority and responsibility for the entire PD process. He is not only a project manager, he also guides a group of engineers which detail the product and represents technical systems integrator. This unique role is the bond that should hold the entire product development and design department and its respective activities together.

\begin{tabular}{|c|c|c|c|}
\hline \multicolumn{2}{|r|}{ Principle } & Crucial aspects, goals & Tools, methods, activities \\
\hline \multirow{3}{*}{ 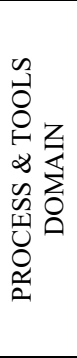 } & $\begin{array}{l}1.0 \text { Individualized } \\
\text { customer policy }\end{array}$ & $\begin{array}{l}\text { Unlimited individualization possibilities represent a } \\
\text { key value-added attribute in customer perceived } \\
\text { product value. }\end{array}$ & $\begin{array}{l}\text { Standardize the product architecture instead of a set of } \\
\text { available components to ensure modular design structure } \\
\text { with unlimited interchangeability of components. }\end{array}$ \\
\hline & $\begin{array}{l}\text { 2.0 Standardized design } \\
\text { approach }\end{array}$ & $\begin{array}{l}\text { Turn the development and design departments into } \\
\text { efficient and easy manageable environments with } \\
\text { predictable outcomes. }\end{array}$ & $\begin{array}{l}\text { Establish a library of standard parts, subassemblies, and } \\
\text { start-up platforms. Consolidate the design approach and } \\
\text { standardize the design techniques. }\end{array}$ \\
\hline & $\begin{array}{l}\text { 3.0 Extensive data } \\
\text { management with } \\
\text { advanced IT support }\end{array}$ & $\begin{array}{l}\text { Transparent overview over relevant project data } \\
\text { and its appropriate management gets difficult as the } \\
\text { complexity of a product increases. Established } \\
\text { overall data management is a key feature of robust } \\
\text { PD process. }\end{array}$ & $\begin{array}{l}\text { Minimize fault generation, automate and accelerate the } \\
\text { design process with IT development. Introduce expert } \\
\text { system, establish parametric data flow, and apply PLM } \\
\text { systems. }\end{array}$ \\
\hline \multirow{2}{*}{ 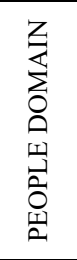 } & $\begin{array}{l}4.0 \text { Involvement of } \\
\text { suppliers }\end{array}$ & $\begin{array}{l}\text { Timely definition of feasible product ranges } \\
\text { reduces PD time and enhances product and process } \\
\text { efficiency. }\end{array}$ & $\begin{array}{l}\text { Establish long-term partnerships. Develop professional } \\
\text { competences (generate new knowledge) with mutual } \\
\text { exchange and exploration of new design possibilities. }\end{array}$ \\
\hline & 5.0 Robust team structure & $\begin{array}{l}\text { Concurrent cooperation of independent experts } \\
\text { results in maximum time performance with } \\
\text { advanced and deepened special knowledge and } \\
\text { skills acquired by individuals. }\end{array}$ & $\begin{array}{l}\text { Establish a clear project team hierarchy. Promote a } \\
\text { heavyweight chief engineer and convert the design team } \\
\text { to suit a conveyor belt principle. Introduce the project } \\
\text { manager, a competent link between customers, suppliers, } \\
\text { chief engineer, engineering designers and production. }\end{array}$ \\
\hline \multirow{3}{*}{ 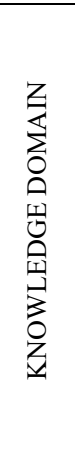 } & 6.0 Knowledge generation & $\begin{array}{l}\text { Constant investments into development of products } \\
\text { enhances multiple aspects: creativity, productivity, } \\
\text { and the competitive position of a company. }\end{array}$ & $\begin{array}{l}\text { Establish research and development team(s), responsible } \\
\text { for the generation of a new knowledge. Research activities } \\
\text { run in parallel with current work. They are tested on } \\
\text { concrete projects, predefined milestones, and are brought } \\
\text { to production after positive, technical, and economic } \\
\text { validation. }\end{array}$ \\
\hline & $\begin{array}{l}7.0 \text { Knowledge } \\
\text { management }\end{array}$ & $\begin{array}{l}\text { Preserving and mastering knowledge gained from } \\
\text { previous projects is essential for competent and } \\
\text { efficient new PD process. Experience shows that } \\
\text { almost any 'new' solution has once already been } \\
\text { discovered. }\end{array}$ & $\begin{array}{l}\text { Establish a knowledge database system. Promote } \\
\text { mentoring between senior engineers and new associates. } \\
\text { Transform into a continuous-learning organization. }\end{array}$ \\
\hline & $\begin{array}{l}8.0 \text { Company's culture } \\
\text { transformation to lean }\end{array}$ & $\begin{array}{l}\text { Every successful change begins with a change in } \\
\text { mind-set. A company has to strive for continuous } \\
\text { improvement of its processes. }\end{array}$ & $\begin{array}{l}\text { Persist in introduced changes. Taking shortcuts usually } \\
\text { return the process to its starting point. }\end{array}$ \\
\hline
\end{tabular}

The field of suppliers is another important feature of the People level. It is obvious that role of suppliers represents an elementary part of any LPD system. Companies should manage and nurture their suppliers in the same way they manage and nurture their internal manufacturing and engineering resources. Pre-sourcing arrangements should get them on board from the start so that they are involved from the earliest stages in concept development.

\subsection{Knowledge Level}

Organizational learning is an obligatory precondition for ceaseless progress which supports all other principles. The ability of a company to expand and retain the knowledge and skills of its personnel may turn into sustainable competitive advantage. Constant interaction with suppliers, enriching engineering knowledge, and investing in human resources seem to be the most important aspects of this domain. Short development lead times are coupled with its independent ability to learn, as the organization creates fast and effective learning cycles, which accelerate their continuous improvement engine [35]. The presented case study confirmed this assertion. Technology has to have the ability to be individualized and subordinated to the people and process. Optimization of software tools, combined with a standardization process, is therefore of great importance whereas the retention of applied decisions, over the longer period, is also crucial. Table 1 summarised the applied actions to transform the case study PD process in Knowledge domain.

\section{DISCUSSION AND RESULTS OF APPLYING LEAN METHODS}

TPDS has been a widely studied and researched engineering paradigm in the past two decades as it represents a fundamental and universal engineering approach to an efficient PD process in serial production environments. In mass production, even a tiny optimization can, over time and via numerous repetitions result in significant savings. Lean development of individualized 
products pursues other objectives. Successful management of never-ending engineering changes seems to be the most important aspect in this field. Accordingly, introducing lean into a highly individualized development activities is mostly about enhancing the robustness of the new PD process, which results in minimized rework activities and forced engineering changes, improved reputation on the market, and increased excellence of a company. This work aims at delivering a successful case study and a generalized framework of lean approach introduction into OKP environment. It presents how companies under such specific business conditions can benefit and raise their profitability through the implementation of LPD concepts.

An analysis of PD process renovation, according to lean approach in OKP production environment, indisputably showed that lean principles, known from mass production, could generally be introduced in such a specific business environment. However, several adjustments are inevitable, as both business models differ substantially in some crucial aspects. Tab. 2 shows a detailed list of savings, which were recognized as a direct consequence of implied renovation. The values in this table were obtained via the performance analysis of conducted projects of a sample subassembly (Fig. 4) during a one-year test period. Although results for different subassemblies may vary, a similar general trend was noticed. Significant savings were recorded despite varying the specifics of each individual subassembly. In Tab. 1, a generalized framework of a robust, LPD process for one-of-a-kind PD is proposed.

Table 2 Complete list of savings, resulting in PD process renovation according to lean methodology

\begin{tabular}{|l|c|c|c|c|c|c|}
\hline \multicolumn{1}{|c|}{ Item } & $T_{\mathrm{PREP}} / \mathrm{min}$ & $T_{3 \mathrm{D}} / \mathrm{hrs}$ & $T_{\mathrm{DRW}} / \mathrm{hrs}$ & $T_{\mathrm{TOTAL}} / \mathrm{hrs}$ & Project rate $/$ year & EC rate $/ \%$ \\
\hline Before implementation & 60 & 16 & 24 & 40 & 45 \\
\hline After implementation & 10 & 5 & 18 & 23 & 78 \\
\hline Performance improvement & 50 & 11 & 6 & 17 & 33 \\
\hline & $83 \%$ & $69 \%$ & $25 \%$ & $43 \%$ & 4 \\
\hline
\end{tabular}

$T_{\text {PREP }}=$ time for preparation. All necessary data for an uninterrupted design process are gained during this time.

$T_{3 \mathrm{D}}=$ time necessary for the completion of a 3D design of the featured assembly (magnetic core).

$T_{\mathrm{DRW}}=$ time necessary for the completion of a corresponding technical documentation.

$T_{\text {TOTAL }}=$ total design time $\left(T_{3 \mathrm{D}}+T_{\mathrm{DRW}}\right)$

Project rate $=$ number of realized projects per year (per person).

$E C$ rate $=$ percentage of realized projects where engineering change was necessary (rework).
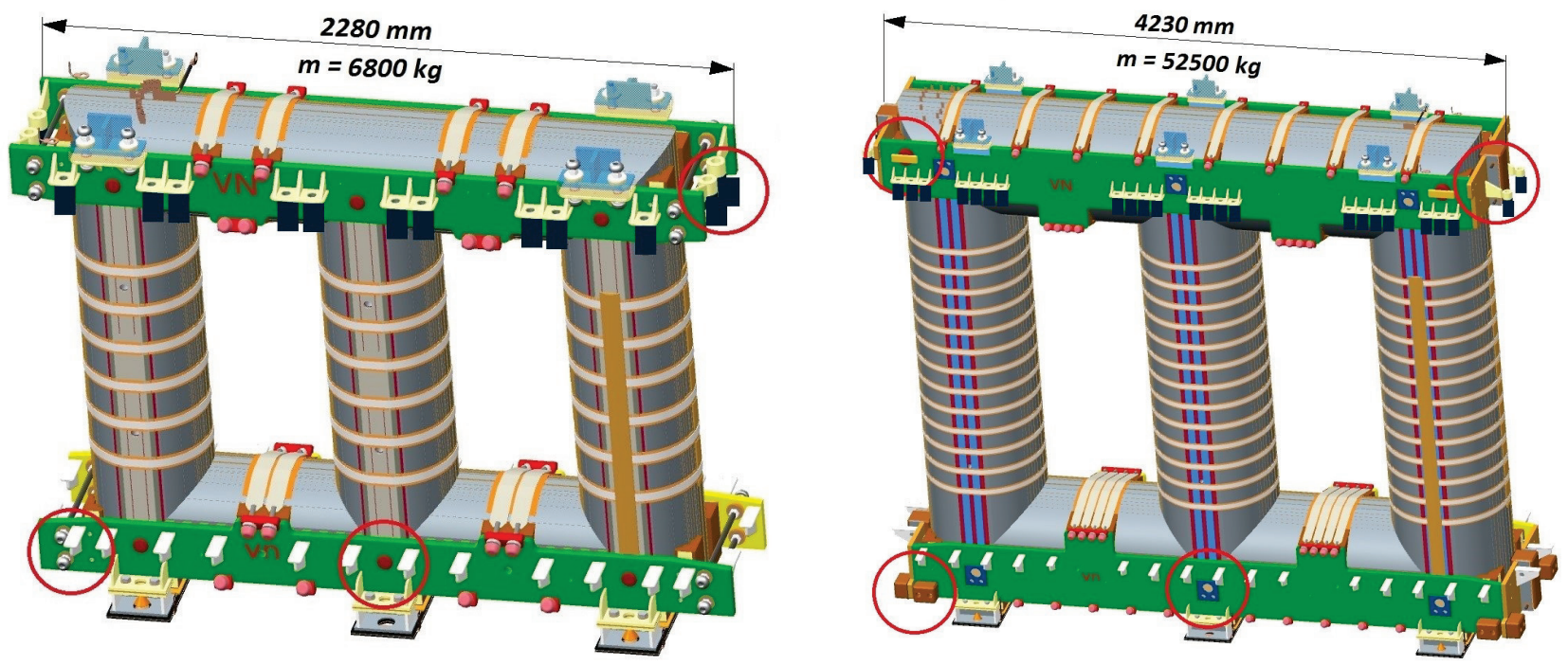

Figure 4 Fully parametric 3D platform of a magnetic circuit. The scalable platform with built-in modular attributes (marked with red circles) enables the model to be customized and adjusted according to new design parameters and customer specifications in a considerably short amount of time. The efficient iterative process enables late design decisions.

Fig. 5 shows the number of completed projects in mechanical design department for the studied product segment. The analysis clearly shows a considerable drop in necessarily engineering changes, which are the consequence of non-optimal product design. The results are in direct association with the enhanced robustness of the development and design process.

The sample company experienced radical changes during the renovation presented by this case study. Analysis of state with definition of value and separation of waste was initiated with introduction of relevant leanbased tools (i.e. IDEF0, VSM). As relevant data was gained, the core of the PD and design process was taken into consideration. Turning the company towards a smart factory, an expert system was implemented and effective data management solutions (PLM system) were introduced. Standardization was enhanced on several levels. Special focus was put on the development of standardized design processes, highly modular design structure, consolidation of design techniques, and a library of standard parts subassemblies. Parallel to Process and tools level, progress was made also on people and knowledge level. Project teams with flexible organisation, a project management office that efficiently links the departments of Design, Sales and Procurement, together with building up engineering knowledge through most experienced staff, were recognized to be among the most important measures. Constant interaction with suppliers was confirmed to be essential for the long-term quality assurance. Individualized production turned out to be 
strongly dependent on specific production, technology knowledge, and reliable, robust and predicted process flow [34]. The results shown in Tab. 2 demonstrate the suitability of the methodology used in the presented case study. Based on this, we propose a competent standardized framework of a robust, LPD process in one-of-a-kind PD environment in Tab. 1.

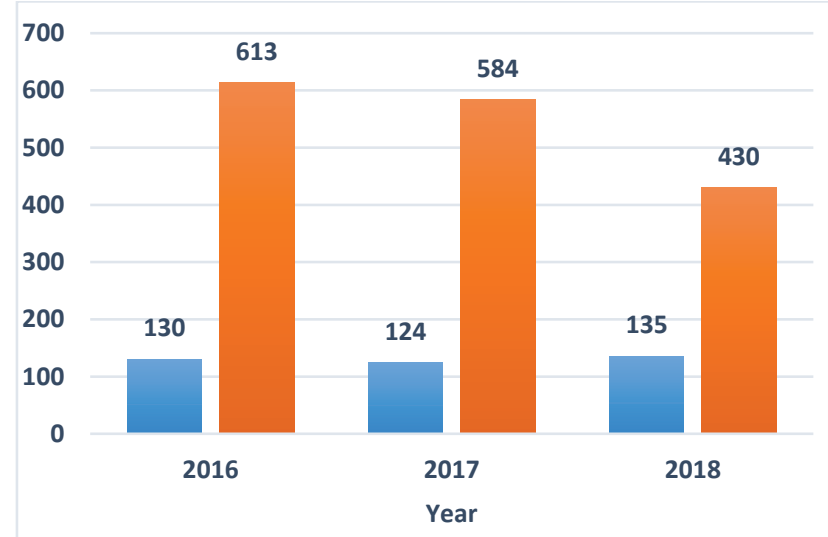

Number of projects Number of engineering changes

Figure 5 Engineering changes per year in comparison to completed projects.

\section{CONCLUSIONS}

This study presents an extensive transformation of one-of-a-kind PD process according to Toyota's methodology of lean. The focus of comprehensive renovation has been placed on reducing waste and increasing agility and smartness of the design process in a specific, highly individualized production environment. Research results in a definition of generalized framework of PD and design process renovation, comprising three main fields of interest: Process \& Tools, People, and Knowledge. Results show that the principles under the groups of People and Knowledge may be generalized in a great manner. Furthermore, the principles of the group Process \& Tools are complex and strongly define each individual PD process. Standardization of the product architecture instead of its components was found crucial to ensure modular design structure with unlimited interchangeability of components. Standardized design approach can be achieved by establishment of a library of standard parts, subassemblies and smart start-up platforms. Consolidated design approach and standardized design techniques resulted in efficient and easy manageable PD process. Introduction of expert system, parametric data flow and application of PLM system, tailored to company needs, resulted in fault minimization. The proposed framework (Tab. 1) is generalized, which makes it directly applicable in similar business environments.

Research revealed that some limitation exist. Transparent overview over relevant project data and its appropriate management gets difficult as the complexity of a product increases. Presented principles have to be attentively tuned with the nature of the respective PD process. TPDS cannot be simply introduced into one-of-akind business environment, rather it has to be individually altered to optimally accommodate the respective process.
Quantitative analyses (Tab. 2 and Fig. 5) indicates that the proposed approach results in extensive savings in all relevant business aspects. Savings are expressed as a combination of direct savings (reduced development cycletime, time-to-market, rework, man-hours, etc.) and indirect savings (improved knowledge management, increased company reputation, etc.). Case-study company cut down engineering changes by $32 \%$ in three year test period and experienced performance improvement between $25 \%$ and $83 \%$ across designated process indicators. Despite the specific case presented in this study, the results indicate a possible and reasonable wider application of the proposed approach in the OKP domain.

\section{Acknowledgement}

This work was supported by Slovenian Research Agency - ARRS, grant number contract no. P2-0265.

\section{REFERENCES}

[1] Womack, J. P. \& Jones, D. T. (1997). Lean Thinking, Banish Waste and Create Wealth in your Corporation. New York, NY: Touchstone Books. https://doi.org/10.1057/palgrave.jors.2600967

[2] Tokola, H., Niemi, E., \& Kyrenius, P. (2017). How Lean Transformation affects Scheduling. Robotics and ComputerIntegrated Manufacturing, 43(SI), 171-178. https://doi.org/10.1016/j.rcim.2015.09.012

[3] Conforto, E. C. \& Amaral, D. C. (2016). Agile Project Management and stage-gate Model - A Hybrid Framework for technology-based Companies. Journal of Engineering and Technology Management, 40, 1-14. https://doi.org/10.1016/j.jengtecman.2016.02.003

[4] Bayou, M. E. \& de Korvin, A. (2008). Measuring the Leanness of Manufacturing Systems - A Case Study of Ford Motor Company and General Motors. Journal of Engineering and Technology Management, 25, 287-304. https://doi.org/10.1016/j.jengtecman.2008.10.003

[5] Khalil, R. A. \& Stockton, D. J. (2010). Predicting the Effects of Cycle Time Variability on the Efficiency of Electronics Assembly Mixed-Model, Zero-Buffer Flow Processing Lines. International Journal of Computer Integrated Manufacturing, 23(12), 1149-1157. https://doi.org/10.1080/0951192X.2010.500679

[6] Khan, M.S., Al-Ashab, A., Shehab, E., Haque, B., Ewers, P., Sorli, M., \& Sopelana, A. (2013). Towards Lean Product and Process Development. International Journal of Computer Integrated Engineering, 26(12), 1105-1116. https://doi.org/10.1080/0951192X.2011.608723

[7] Haque, B. \& James-Moore, M. (2004). Applying Lean Thinking to New Product Introduction. Journal of Engineering Design, 15, 1-31. https://doi.org/10.1080/0954482031000150125

[8] Radeka, K. (2007). The Toyota Product Development System: Integrating People, Process and Technology - book review. Journal of Product Innovation Management, 24, 274-281. https://doi.org/10.1111/j.1540-5885.2007.00250_1.x

[9] Schulze, A. \& Störmer, T. (2012). Lean Product Development - Enabling Management Factors for Waste Elimination. International Journal of Technology Management, 57(1-3), 72-91. https://doi.org/10.1504/IJTM.2012.043952

[10] Furuhjelm, J., Håkan, S., \& Tingström, J. (2011). Creating Value through Lean Product Development - Applying Lean Principles. International Conference on Engineering Design, ICED11, 489-497. 
[11] Baines, T., Lightfoot, H., Williams, G. M., \& Greenough, R. (2006). State-of-the-art in Lean Design Engineering: A Literature Review on White Collar Lean. Journal of Engineering Manufacture, 220, 1539-1547. https://doi.org/10.1243/09544054JEM613

[12] Hoppmann, J., Rebentisch, E., Dombrowski, U., \& Zahn, T. (2011). A Framework for Organizing Lean Product Development. Engineering Management Journal, 23(1), 315. https://doi.org/10.1080/10429247.2011.11431883

[13] Ghobakhloo, M. \& Azar, A. (2018). Business Excellence via Advanced Manufacturing Technology and Lean-agile Manufacturing. Journal of Manufacturing Technology Management, 29(1), 2-24. https://doi.org/10.1108/JMTM-03-2017-0049

[14] Womack, J. P., Jones, D. T., \& Roos, D. (1990). The Machine that Changed the World. New York, NY: Rawson Associates.

[15] Clark, K. B., Chew, W. B., \& Fujimoto, T. (1987). Product Development in the World Auto Industry. Brookings Papers on Economic Activity, 729-781. https://doi.org/10.2307/2534453

[16] Karlsson, C. \& Ahlström, P. (1996). The Difficult Path to Lean Product Development. Journal of Product Innovation Management, 13(4), 283-295. https://doi.org/10.1111/1540-5885.1340283

[17] Morgan, J. M. \& Liker, J. K. (2006). The Toyota Product Development System: Integrating People, Process and Technology. New York, NY: Productivity Press. https://doi.org/10.4324/9781482293746

[18] Ward, A. C., Shook, J., \& Sobek, D. K. II. (2007). Lean Product and Process Development. Cambridge, MA: The Lean Enterprise Institute.

[19] Stjepandić, J., Wognum, N., \& Werhagen, W. J. C. (eds.). (2015). Concurrent Engineering in the 21 $1^{\text {st }}$ Century: Foundations, Developments and Challenges. Cham [etc.]: Springer. https://doi.org/10.1007/978-3-319-13776-6

[20] Belvedere, V., Cuttaia, F., Rossi, M., \& Stringhetti, L. (2019). Mapping Wastes in Complex Projects for Lean Product Development. International Journal of Project Management, 37(3), 410-424 https://doi.org/10.1016/j.jiproman.2019.01.008

[21] Lee, J., Bagheri, B., \& Kao, H.A. (2015). A Cyber-physical Systems Architecture for Industry 4.0-based Manufacturing Systems. Manufacturing Letters, 3, 18-23. https://doi.org/10.1016/j.mfglet.2014.12.001

[22] Liao, Y., Deschamps, R., Loures, E. F. R., \& Ramos, L. F. P. (2017). Past, Present and Future of Industry 4.0 - A Systematic Literature Review and Research Agenda Proposal. International Journal of Production Research, 55(12), 3609-3629. https://doi.org/10.1080/00207543.2017.1308576

[23] Wang, L., Törngren, M., \& Onori, M. (2015). Current Status and Advancement of Cyber-physical Systems in Manufacturing. Journal of Manufacturing Systems, 37(2), 517-527. https://doi.org/10.1016/j.jmsy.2015.04.008

[24] Letens, G., Farris, J.A., \& Van Aken, E.M. (2011). A Multilevel Framework for Lean Product Development System Design. Engineering Management Journal, 23(1), 69-85. https://doi.org/10.1080/10429247.2011.11431887

[25] Tavčar, J., Demšar, I., \& Duhovnik, J. (2018). Engineering Change Management Maturity Assessment Model with Lean Criteria for Automotive Supply Chain. Journal of Engineering Design, 29(4/5), 235-257. https://doi.org/10.1080/09544828.2018.1463513

[26] Rivera, L. \& Chen, F. F. (2007). Measuring the Impact of Lean Tools on the Cost-time Investment of a Product Using Cost-time Profiles. Robotics and Computer-Integrated Manufacturing, 23(6), 684-689. https://doi.org/10.1016/j.rcim.2007.02.013
[27] Gjeldum, N., Veža, I., \& Bilić, B. (2011). Simulation of Production Process Reorganized with Value Stream Mapping. Technical Gazette, 18(3), 341-347.

[28] Veza, I., Mladineo, M., \& Gjeldum, N. (2016). Selection of the Basic Lean Tools for Development of Croatian Model of Innovative Smart Enterprise. Technical Gazette, 23(5), 1317-1324. https://doi.org/10.17559/TV-20160202120909

[29] Kennedy, B. M., Sobek, D. K. II \& Kennedy, M. N. (2014). Reducing Rework by Applying Set-Based Practices Early in the Systems Engineering Process. System Engineering, 17(3), 278-296. https://doi.org/10.1002/sys.21269

[30] Zheng, P., Lu, Y., Xu, X., \& Xie, S.Q. (2017). A System Framework for OKP Product Planning in a Cloud-based Design Environment. Robotics and Computer-Integrated Manufacturing, 45(SI), 73-85. https://doi.org/10.1016/j.rcim.2016.04.001

[31] Tavčar, J. \& Duhovnik, J. (2005). Engineering Change Management in Individual and Mass Production. Robotics and Computer-Integrated Manufacturing, 21(3), 205-215. https://doi.org/10.1016/j.rcim.2004.07.017

[32] Duhovnik, J. \& Tavčar, J. (2015). Concurrent Engineering in Machinery, Chapter 22. In: Stjepandić, J., N. Wognum and W. J. C. Werhagen (eds.). 2015. Concurrent Engineering in the 21st Century: Foundations, Developments and Challenges. Cham [etc.]: Springer. https://doi.org/10.1007/978-3-319-13776-6_22

[33] Álvarez, R., Calvo, R., Peña, M. M., \& Domingo, R. (2008). Redesigning an Assembly Line through Lean Manufacturing Tools. International Journal of Advanced Manufacturing Technology, 43(9-10), 949-958. https://doi.org/10.1007/s00170-008-1772-2

[34] Varl, M., Duhovnik, J., \& Tavčar, J. (2016). Towards a Model for Robust Design and Design Process in One-of-aKind Production of Large Power Transformers. International Journal of Agile Systems and Management, 9(1), 67-88. https://doi.org/10.1504/IJASM.2016.076578

[35] Tavčar, J., Demšar, I., \& Varl, M. (2019). Knowledge Management Support of Engineering Change Management and Adaptive Design in Serial and One-of-a-kind Production: chapter 2. In: GRAHAM, Travis (ed.). Knowledge management: progress, trends and challenges. New York: Nova Science, 31-93.

\section{Contact information}

Mitja VARL

Kolektor ETRA, d.o.o

Šlandrova ulica 10

1231 Ljubljana, Slovenia

E-mail: mitja.varl@kolektor.com

Jože DUHOVNIK, PhD, Prof.

University of Ljubljana

Faculty of Mechanical Engineering

Aškerčeva 6

1000 Ljubljana, Slovenia

E-mail: joze.duhovnik@lecad.fs.uni-lj.si

\section{Jože TAVČAR, PhD}

(Corresponding author)

University of Ljubliana

Faculty of Mechanical Engineering

Aškerčeva 6

1000 Ljubljana, Slovenia

E-mail: joze.tavcar@lecad.fs.uni-li.si 